\title{
THE TOXIC EFFECTS OF CARBON DIOXIDE AND ACETAZOLAMIDE IN HEPATIC ENCEPHALOPATHY *
}

\author{
By JEROME B. POSNER ANd FRED PLUM
}

\author{
(From the Division of Neurology, Department of Medicine, University of Washington School \\ of Medicine, Seattle, Wash.)
}

(Submitted for publication November 2, 1959; accepted January 15, 1960)

Striking alterations in respiratory gas and blood ammonia levels usually accompany hepatic coma. The arterial $\mathrm{pH}$ is elevated and the carbon dioxide tension reduced (1). The blood ammonia level (2-4) is increased in many instances and the brain arteriovenous ammonia difference is high $(5,6)$. The cerebral oxygen uptake is depressed $(7,8)$.

Whether the pronounced alkalosis which accompanies many instances of hepatic coma contributes to the encephalopathy is unknown. Severe blood alkalosis impairs oxyhemoglobin dissociation (9), lowers the arterial oxygen partial pressure and interferes with cerebral function in normal subjects (10). Alkalosis is reported to enhance ammonia toxicity (11-13). These effects led Roberts and associates (14) as well as others (13) to suggest using carbon dioxide inhalation to treat hepatic coma. Preliminary clinical observations on our own services suggested that inhaled $\mathrm{CO}_{2}$ worsened rather than improved patients with the encephalopathy of liver disease. Accordingly, detailed clinical and cerebral metabolic studies were carried out to quantitate the effects on brain function of raising blood and tissue $\mathrm{CO}_{2}$ tensions. The results of the study are reported here. Cerebral blood flow and cerebral oxygen uptake were measured at rest in control and cirrhotic patients and the results were correlated with the patients' mental and somatic neurological function. Following the baseline study, selected patients inhaled carbon dioxide and the clinical cerebral metabolic observations were repeated. Subsequently, to eliminate the undesirable side effects of hyperpnea and dyspnea as contributing to the observed changes, similar observations were made before and after raising tissue $\mathrm{CO}_{2}$ tensions by rapidly infusing acetazolamide (Diamox).

* Aided by a grant (2B-5067) from the United States Public Health Service.
MATERIALS, PROCEDURE AND METHODS

\section{Materials}

A total of 17 patients with hepatic cirrhosis diagnosed by the usual clinical and laboratory criteria were selected from the wards and clinics of the King County Hospital, Seattle. Eleven patients of comparable age, lacking cirrhosis or other diseases known to affect cerebral metabolism, served as "normal" controls. Four noncirrhotic patients with old clinically-stable brain lesions (one with focal brain infarction, two with diffuse, moderate cerebral arteriosclerosis, and one with posthypoglycemic brain damage) served as controls for studying the effect of $\mathrm{CO}_{2}$ inhalation on cerebral metabolism. One of these subjects and four additional subjects with cerebral arteriosclerosis served as controls when the effects of acetazolamide on hepatic encephalopathy were studied. All patients and controls received careful mental and neurological examinations. The degree of encephalopathy in the cirrhotics was graded from 0 to 4 using the following criteria.

Crade 0 . The patients were fully alert and oriented. They had intact recent memory and performed serial sevens or serial threes correctly and easily. The somatic neurological examination was normal. The respiratory rate and depth appeared normal.

Grade 1. The patients were fully alert and oriented. Although recent memory was good, mental testing uncovered errors, e.g., date of admission to hospital. Serial sevens were mildly impaired. The somatic neurological examination was normal. The respiratory rate and depth appeared normal. Since presumably normal persons from a similar age group and socioeconomic background frequently show this minimal impairment, Grade 1 was considered uncertain evidence for encephalopathy and was clinically classified with Grade 0 for metabolic analysis.

Gradc 2. The patients were lethargic and mildly confused. They usually were oriented correctly to person and place but incorrectly to time. Serial sevens were performed poorly. Most patients had arrhythmic lateral twitching of the extended fingers and some had the classic "metabolic flap" described by Adams and Foley (15) The respiratory rate and depth appeared normal.

Grade 3. The patients were frankly confused and intermittently somnolent. Disorientation was usually complete so that appropriate conversation was impossible. The somatic neurological examination often elicited hy- 
peractive deep tendon reflexes, paratonic rigidity and extensor plantar responses. A metabolic flap was invariably present.

Grade 4. The patients were comatose and responded only to vigorous painful stimuli. They were obviously hyperventilating.

\section{Procedure}

All patients were taken to the laboratory in the early morning before breakfast. A mental and somatic neurological examination was performed. Following this, no. 18 needles were inserted into the femoral artery and jugular bulb (16), and a snugly fitting face mask was applied. The blood pressure and alveolar $\mathrm{CO}_{2}$ tension $\left(\mathrm{PACO}_{2}\right)$ were monitored. The patients rested for $20 \mathrm{~min}$ utes or more while respiratory exchange and blood pressure stabilized. Cerebral blood flow using 15 per cent $\mathrm{N}_{2} \mathrm{O}, 21$ per cent $\mathrm{O}_{2}$, and 64 per cent $\mathrm{N}_{2}$ was then determined. During the determination each patient was observed repeatedly for variations in muscular tremor and resistance. At the end of this first procedure, all patients rested 10 to 15 minutes. Following this rest period, the effects of inhaled $\mathrm{CO}_{2}$ or infused acetazolamide were then studied in selected subjects.

To determine the effects of inhaled $\mathrm{CO}_{\sharp}$, subjects were placed on 5 per cent $\mathrm{CO}_{2}$ in air for approximately 20 minutes to develop a stable response to the gas. After this adaptation, the gas mixture was switched to 15 per cent $\mathrm{N}_{2} \mathrm{O}, 5$ per cent $\mathrm{CO}_{2}, 21$ per cent $\mathrm{O}_{2}$ and 59 per cent $\mathrm{N}_{2}$, and the cerebral blood flow was repeated, muscular tremor and resistance being watched closely throughout. Detailed mental and neurological testing was repeated as soon as $\mathrm{CO}_{2}$ breathing terminated.

To determine the effects of acetazolamide, 0.5 to $2 \mathrm{~g}$ of the drug was infused intravenously, several minutes being allowed for administration. Thirty minutes later the cerebral blood flow determination was repeated, with the mental and somatic neurological examination being repeated at the end of this second procedure.

\section{Methods}

The cerebral blood flow was determined by Scheinberg and Stead's modification (17) of Kety and Schmidt's original method (18). Slight variations improved the technique's accuracy (19). The 10 -minute samples were machine-drawn at a constant rate to assure more accurate integration. Calculations (17) included arithmetical correction for dead space between vessel and syringe (19).

Blood was collected in heparin-washed syringes, immediately capped and mercury-sealed. Care was taken to avoid air bubbles. Immediately after drawing, the blood $\mathrm{pH}$ was determined at $37^{\circ} \mathrm{C}$ with a Beckman microelectrode attached to a Cambridge model $\mathrm{R} \mathrm{pH}$ meter. Each sample was repeatedly measured until duplicate agreement of $0.01 \mathrm{pH}$ unit was achieved. The duplicate blood oxygen and carbon dioxide contents were measured manometrically by Peters and Van Slyke's method (20), and the arterial carbon dioxide tension ( $\left.\mathrm{Paco}_{2}\right)$ was determined on the Singer and Hastings nomogram (21). Oxygen tension was estimated from the Dill nomogram, using Severinghaus' correction factors for $\mathrm{pH}$ (22). The blood nitrous oxide was measured by Kety and Schmidt's method (18), each sample being repeated until duplicate agreement of 0.02 volume per cent was achieved. The blood ammonia was determined by Seligson and Hirahara's method (23) and the mean of the two closest of three determinations was the figure chosen.

The arterial blood pressure was recorded directly from the femoral artery through a Statham transducer and a Sanborn strain gage amplifier. The expired carbon dioxide was monitored by an infrared analyzer (Liston-Becker), gas samples being drawn continuously through a needle in the patient's mask.

\section{RESULTS}

\section{Normal values}

Table I lists the mean respiratory gas and cerebral metabolic values of eleven "normal" control patients. The mean arterial blood $\mathrm{pH}$ (7.42) and $\mathrm{Pa}_{\mathrm{CO}_{2}}$ (38 $\mathrm{mm} \mathrm{Hg}$ ) were similar to the values of other investigators (22). The mean cerebral blood flow (CBF, $53 \mathrm{ml}$ per $100 \mathrm{~g}$ per minute), arteriovenous oxygen difference $(\mathrm{A}-\mathrm{V}, 6.6$ volumes per cent) and cerebral metabolic rate for oxygen ( $\mathrm{CMR}_{\mathrm{O}_{2}}, 3.4 \mathrm{cc}$ per $100 \mathrm{~g}$ per minute) were virtually identical with Kety and Schmidt's data on normal subjects (18) but significantly lower than Scheinberg and Stead's (17). To check our methods, each of three patients with static central nervous system disease had cerebral blood flows determined on two different days. The $\mathrm{CBF}$ and $\mathrm{A}-\mathrm{V}_{\mathrm{O}_{2}}$ differences varied considerably between determinations, but the $\mathrm{CMR}_{\mathrm{O}_{2}}$ showed a standard deviation of 0.182 , a value similar to Kety and Schmidt's 0.187 .

\section{Cerebral metabolism in cirrhosis}

Blood $p H$. Table I and Figure 1 show the arterial $\mathrm{pH}$ levels from cirrhotic patients in Grades 0 to 4 . There was overlapping between individual $\mathrm{pH}$ values accompanying different grades of encephalopathy although patients with moderate and severe encephalopathy had higher mean $\mathrm{pH}$ determinations than did patients graded 0 to 2 . All but one of the patients without encephalopathy were alkalotic (mean $\mathrm{pH} 7.48$ ), although clinically evident hyperventilation was absent. Most Grade 3 patients had higher arterial blood 
TABLE I

Cerebral metabolism in cirrhosis

\begin{tabular}{|c|c|c|c|c|c|c|c|}
\hline $\begin{array}{l}\text { Name, Age, } \\
\text { Sex }\end{array}$ & Art. $\mathrm{pH}$ & Art. $\mathrm{O}_{2}$ & Est. $\mathrm{Po}_{2}$ & $\mathrm{PaCO}_{2}$ & Cerebral A-Vo 2 & CBF* & $\mathrm{CMRO} \dagger$ \\
\hline Mean, 11 normals & $7.42 \pm 0.03$ & $\begin{array}{c}\text { Sat. } \% \\
95.2 \pm 2.0\end{array}$ & $\begin{array}{c}m m \mathrm{Hg} \\
89\end{array}$ & $\begin{array}{l}m m \mathrm{Hg} \\
38 \pm 5\end{array}$ & $\begin{array}{c}\text { vol \% } \\
6.61 \pm 1.09\end{array}$ & $\begin{array}{c}\mathrm{ml} / 100 \mathrm{~g} / \mathrm{min} \\
53 \pm 8\end{array}$ & $\begin{array}{c}c c / 100 \mathrm{~g} / \mathrm{min} \\
3.4 \pm 0.6\end{array}$ \\
\hline \multicolumn{8}{|l|}{ Grade 0} \\
\hline $\begin{array}{ll}\text { V.McL. } & 42 \text { \% } \\
\text { M.R. } & 49 \sigma^{7} \\
\text { G.B. } & 50 \sigma^{7}\end{array}$ & $\begin{array}{l}7.47 \\
7.42 \\
7.51\end{array}$ & $\begin{array}{l}91.8 \\
90.9 \\
86.1\end{array}$ & $\begin{array}{l}62 \\
61 \\
48\end{array}$ & $\begin{array}{l}29 \\
30 \\
35\end{array}$ & $\begin{array}{l}4.83 \\
5.13 \\
5.49\end{array}$ & $\begin{array}{l}70 \\
64 \\
51\end{array}$ & $\begin{array}{l}3.4 \\
3.3 \\
2.8\end{array}$ \\
\hline \multicolumn{8}{|l|}{ Grade 1} \\
\hline $\begin{array}{ll}\text { A.A. } & 47 \% \\
\text { E.deS. } & 58 \sigma^{7} \\
\text { F.W. } & 48 \sigma^{7}\end{array}$ & $\begin{array}{l}7.52 \\
7.46 \\
7.48\end{array}$ & $\begin{array}{l}92.9 \\
87.0 \\
91.5\end{array}$ & $\begin{array}{l}61 \\
52 \\
60\end{array}$ & $\begin{array}{l}30 \\
38 \\
38\end{array}$ & $\begin{array}{l}6.85 \\
6.31 \\
6.54\end{array}$ & $\begin{array}{l}39 \\
72 \\
55\end{array}$ & $\begin{array}{l}2.7 \\
4.5 \\
3.6\end{array}$ \\
\hline Mean, Grade 0-1 & $7.48 \pm 0.03$ & $90.0 \pm 2.5$ & $57 \pm 5.3$ & $33 \pm 4$ & $5.86 \pm 0.75$ & $59 \pm 12$ & $3.4 \pm 0.6$ \\
\hline \multicolumn{8}{|l|}{ Grade 2} \\
\hline $\begin{array}{ll}\text { L.J. } & 68 \sigma^{7} \\
\text { G.L. } & 72 \sigma^{7} \\
\text { A.G. } & 63 \sigma^{7} \\
\text { L.J. } & 33 \sigma^{7} \\
\text { C.K. } & 50 \sigma^{7} \\
\text { C.K. } & 50 \sigma^{7} \\
\text { M.P. } & 65 \text { \% } \\
\text { H.D. } & 59 \sigma^{7} \\
\text { T.L. } & 33 \text { \% }\end{array}$ & $\begin{array}{l}7.47 \\
7.43 \\
7.49 \\
7.45 \\
7.52 \\
7.49 \\
7.47 \\
7.51\end{array}$ & $\begin{array}{l}94.3 \\
92.5 \\
93.5 \\
92.0 \\
93.5 \\
91.3 \\
94.8 \\
91.9\end{array}$ & $\begin{array}{l}71 \\
66 \\
\\
68 \\
59 \\
65 \\
61 \\
59\end{array}$ & $\begin{array}{c}27 \\
33 \\
36 \\
27 \\
36 \\
28 \\
24.5 \\
22.5\end{array}$ & $\begin{array}{l}7.54 \\
6.76 \\
5.47 \\
4.67 \\
6.63 \\
5.05 \\
6.19 \\
6.97 \\
5.20\end{array}$ & $\begin{array}{l}43 \\
43 \\
51 \\
51 \\
45 \\
59 \\
50 \\
36 \\
48\end{array}$ & $\begin{array}{l}3.2 \\
2.9 \\
2.8 \\
2.4 \\
2.9 \\
3.0 \\
3.1 \\
2.5 \\
2.5\end{array}$ \\
\hline Mean, Grade 2 & $7.48 \pm 0.03$ & $93.0 \pm 1.2$ & $64 \pm 4.3$ & $29 \pm 5$ & $6.05 \pm 0.93$ & $47 \pm 6$ & $\begin{array}{c}2.8 \pm 0.3 \\
\mathrm{p}=<0.01\end{array}$ \\
\hline \multicolumn{8}{|l|}{ Grade 3} \\
\hline $\begin{array}{ll}\text { A.G. } & 63 \sigma^{7} \\
\text { C.K. } & 50 \sigma^{7} \\
\text { C.K. } & 50 \sigma^{7} \\
\text { F.H. } & 54 \sigma^{7} \\
\text { F.H. } & 54 \sigma^{7} \\
\text { E.L. } & 55 \sigma^{7}\end{array}$ & $\begin{array}{l}7.62 \\
7.53 \\
7.49 \\
7.55 \\
7.62 \\
7.51\end{array}$ & $\begin{array}{l}96.0 \\
92.0 \\
93.4 \\
79.1 \\
83.1 \\
92.8\end{array}$ & $\begin{array}{l}70 \\
58 \\
65 \\
38 \\
39 \\
61\end{array}$ & $\begin{array}{l}28 \\
34 \\
32 \\
35 \\
28 \\
24\end{array}$ & $\begin{array}{l}6.43 \\
5.85 \\
3.37 \\
6.32 \\
6.00 \\
5.42\end{array}$ & $\begin{array}{l}33 \\
36 \\
35 \\
34 \\
44 \\
32\end{array}$ & $\begin{array}{l}2.1 \\
2.1 \\
1.2 \\
2.2 \\
2.6 \\
1.8\end{array}$ \\
\hline Mean, Grade 3 & $7.55 \pm 0.05$ & $89.5 \pm 6.1$ & $55 \pm 12.3$ & $30 \pm 4$ & $5.56 \pm 1.15$ & $36 \pm 4$ & $\begin{array}{l}2.0 \pm 0.4 \\
\mathrm{p}=<0.01\end{array}$ \\
\hline \multicolumn{8}{|l|}{ Grade 4} \\
\hline $\begin{array}{ll}\text { G.R. } & 63 \% \\
\text { B.F. } & 84 \% \\
\text { B.F. } & 84 \%\end{array}$ & $\begin{array}{l}7.63 \\
7.57 \\
7.52\end{array}$ & $\begin{array}{l}90.4 \\
93.3 \\
92.3\end{array}$ & $\begin{array}{l}49 \\
59 \\
59\end{array}$ & $\begin{array}{l}22 \\
27 \\
25\end{array}$ & $\begin{array}{l}6.15 \\
8.05 \\
7.38\end{array}$ & $\begin{array}{l}29 \\
20 \\
18\end{array}$ & $\begin{array}{l}1.8 \\
1.6 \\
1.3\end{array}$ \\
\hline Mean, Grade 4 & $7.57 \pm 0.05$ & $92.0 \pm 2.6$ & $56 \pm 4.7$ & $25 \pm 6$ & $7.19 \pm 1.37$ & $22 \pm 5$ & $\begin{array}{c}1.6 \pm 0.2 \\
p=<0.1>0.05\end{array}$ \\
\hline
\end{tabular}

* Cerebral blood flow.

$\dagger$ Cerebral metabolic rate for oxygen.

$\mathrm{pH}$ values (mean 7.55) than did those in Grades 0,1 or 2 , although only one Grade 3 patient showed clinically evident hyperventilation. Both of the Grade 4 patients (one patient studied twice) had an arterial $\mathrm{pH}$ above 7.52 , and both were hyperventilating clinically.

Cerebral oxygen uptake. Table I and Figure 1 show $\mathrm{CMR}_{\mathrm{O}_{2}}$ values from cirrhotic patients. There was a consistent trend toward decreasing cerebral oxygen uptake as encephalopathy worsened. Patients without definite encephalopathy (Grades 0 and 1) had normal cerebral blood flow and oxygen uptake (mean $3.4 \mathrm{cc}$ per $100 \mathrm{~g}$ per minute). Patients with moderate encephalopathy (Grade 2) showed a significant $(\mathrm{p}=<0.01)$ $\mathrm{CMR}_{\mathrm{O}_{2}}$ depression (mean $2.8 \mathrm{cc}$ per $100 \mathrm{~g}$ per minute). The lowered cerebral oxygen uptake was reflected in some Grade 2 subjects by reduced 
RELATIONSHIPS BETWEEN CMRO $_{2}$, PH, AND DEGREE OF ENCEPHALOPATHY

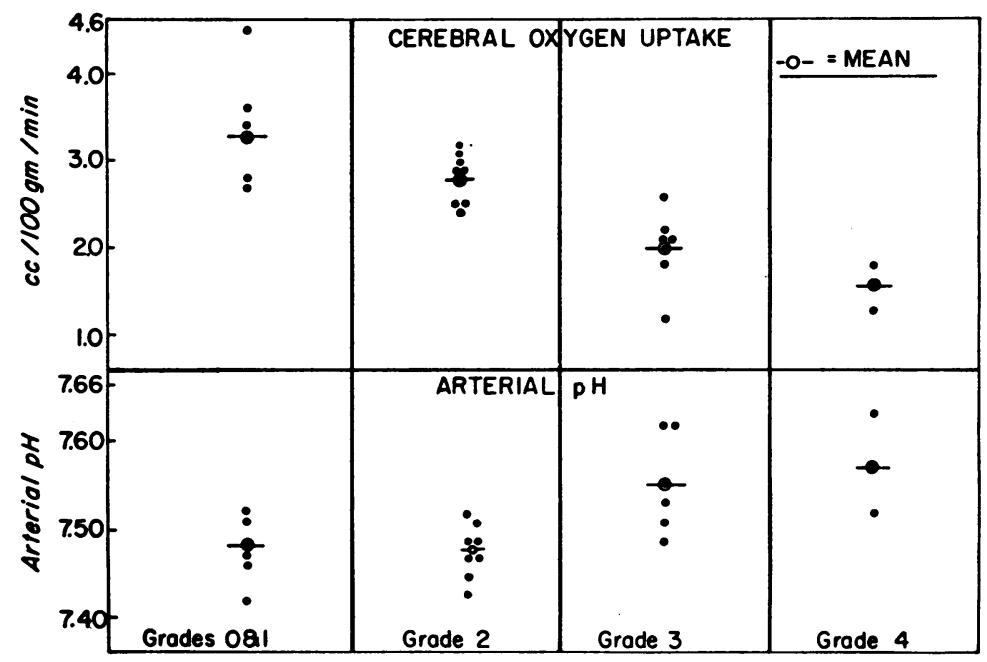

Fig. 1. Cerebral OXYGen UPtake AND ARTERIAL PH VAlues FOR PaTIENTS WITH HEPATIC ENCEPHALOPATHY, GRADED $0-4$.

$\mathrm{CBF}$ and in others by reduced $\mathrm{A}-\mathrm{V}_{\mathrm{O}_{2}}$ differences. All Grade 3 patients had reduced $\mathrm{CBF}$; in none was the cerebral $A-V_{\mathbf{O}_{2}}$ difference raised above normal to compensate for the reduction in flow, and all had reduced $\mathrm{CMR}_{\mathrm{O}_{2}}$ values (mean $2.0 \mathrm{cc}$ per $100 \mathrm{~g}$ per minute). The lowest CBF's were found in the two comatose patients (Grade 4). $\mathrm{A}-\mathrm{V}_{\mathbf{O}_{2}}$ differences were mildly increased but not sufficiently to compensate for the strikingly reduced blood flow, and $\mathrm{CMR}_{\mathrm{O}_{2}}$ was decreased below $2.0 \mathrm{cc}$ per $100 \mathrm{~g}$ per minute (mean $1.6 \mathrm{cc}$ ) in each determination.

\section{Effect of carbon dioxide inhalation}

Clinical response. One cirrhotic and four Grade 0 patients and four noncirrhotic subjects with static brain lesions showed no mental or neurological alterations after inhaling 5 per cent $\mathrm{CO}_{2}$ for 30 minutes. By contrast, five of the eight cirrhotic patients (one patient was studied twice) with encephalopathy became clinically worse during and shortly after inhaling 5 per cent $\mathrm{CO}_{2}$. They showed increased confusion, disorientation and dysarthria, as well as intensified amplitude and frequency of muscular tremor. The mental and neurological deterioration was transient (30 to 120 minutes) in four, but the fifth (L.J.) progressed into coma and died 72 hours later. Paradoxically, L.J. was the only one of the five patients whose clinical deterioration during the second blood flow determination was unaccompanied by a reduced cerebral oxygen uptake.

Metabolic effects. Since the response of cirrhotics without encephalopathy to $\mathrm{CO}_{2}$ inhalation was similar to that of the controls, data in these groups are summarized together in Table II. Table III lists the cerebral metabolic responses of patients with hepatic encephalopathy. Figure 2 compares the $\mathrm{CMR}_{\mathrm{O}_{2}}$ responses in the two groups.

The arterial $\mathrm{pH}$ fell and the $\mathrm{Pa}_{\mathrm{CO}_{2}}$ rose in every patient during $\mathrm{CO}_{2}$ inhalation. These $\mathrm{pH}$ and $\mathrm{PaCO}_{2}$ changes were greater when the patient had encephalopathy, indicating a lesser ventilatory response to $\mathrm{CO}_{2}$. Carbon dioxide inhalation evoked a 33 per cent mean $\mathrm{CBF}$ increase among noncirrhotic controls and a 46 per cent mean CBF increase among cirrhotics. Each group had several subjects in whom $\mathrm{CBF}$ did not increase significantly. These changes are considerably lower than are normal responses of the cerebral circulation to increased $\mathrm{CO}_{2}$ (18) and were to be expected among the controls, three of whom were selected because of arteriosclerotic brain damage. The diminished circulatory response of cirrhotics was unexpected, but may, in part, also be explained by arteriosclerosis, since their mean age was 56 years. In any case, the mean $\mathrm{CBF}$ response was roughly comparable be- 
TABLE II

Cerebral metabolic changes following $\mathrm{CO}_{2}$ inhalation in controls and patients without encephalopathy

\begin{tabular}{|c|c|c|c|c|c|c|c|c|c|c|c|c|c|c|c|}
\hline & & \multicolumn{2}{|c|}{ Art. pH } & \multicolumn{2}{|c|}{$\mathrm{PaCO}_{2}$} & \multicolumn{2}{|c|}{$\begin{array}{c}\text { Cerebral } \\
\mathrm{A}-\mathrm{Vo}_{2}\end{array}$} & \multicolumn{2}{|c|}{$\mathrm{CBF}$} & \multicolumn{2}{|c|}{$\mathrm{CMRO}_{2}$} & \multicolumn{2}{|c|}{$\mathrm{A}-\mathrm{VNH}_{3}$} & \multicolumn{2}{|c|}{$\mathrm{CMRNH}_{3}$} \\
\hline & & Air & $\mathrm{CO}_{2}$ & Air & $\mathrm{CO}_{2}$ & Air & $\mathrm{CO}_{2}$ & Air & $\mathrm{CO}_{2}$ & Air & $\mathrm{CO}_{2}$ & Air & $\mathrm{CO}_{2}$ & Air & $\mathrm{CO}_{2}$ \\
\hline & & & & \multicolumn{2}{|c|}{$m m \mathrm{Hg}$} & \multicolumn{2}{|c|}{ vol \% } & \multicolumn{2}{|c|}{$\underset{\mathrm{gl} / \mathrm{min}}{\mathrm{ml}}$} & \multicolumn{2}{|c|}{$\begin{array}{l}c c / 100 \\
\mathrm{~g} / \mathrm{min}\end{array}$} & \multicolumn{2}{|c|}{$\mu g / m l$} & \multicolumn{2}{|c|}{$\mu \mathrm{g} / 100 \mathrm{~g} / \mathrm{min}$} \\
\hline \multicolumn{16}{|c|}{ Controls } \\
\hline $\begin{array}{l}\text { G.S. } \\
\text { A.Q. } \\
\text { A.H. } \\
\text { O.M. }\end{array}$ & $\begin{array}{l}59 \text { \% } \\
68 \sigma^{7} \\
68 \sigma^{7} \\
57 \text { व }\end{array}$ & $\begin{array}{l}7.45 \\
7.40 \\
7.39 \\
7.52\end{array}$ & $\begin{array}{l}7.41 \\
7.37 \\
7.37 \\
7.49\end{array}$ & $\begin{array}{l}35 \\
37 \\
44 \\
28\end{array}$ & $\begin{array}{l}39 \\
39 \\
46 \\
32\end{array}$ & $\begin{array}{l}5.17 \\
6.74 \\
9.01 \\
4.20\end{array}$ & $\begin{array}{l}4.81 \\
3.01 \\
7.29 \\
4.89\end{array}$ & $\begin{array}{l}60 \\
43 \\
39 \\
52\end{array}$ & $\begin{array}{r}65 \\
101 \\
44 \\
47\end{array}$ & $\begin{array}{l}3.1 \\
2.9 \\
3.5 \\
2.2\end{array}$ & $\begin{array}{l}3.1 \\
3.0 \\
3.2 \\
2.3\end{array}$ & $1.83-1.68$ & $1.73-1.55$ & 5.85 & -0.88 \\
\hline \multicolumn{16}{|c|}{ Cirrhotics } \\
\hline $\begin{array}{l}\text { G.B. } \\
\text { V.McL. } \\
\text { A.A. } \\
\text { E.dS. }\end{array}$ & $\begin{array}{l}50 \text { व } \\
42 \text { \% } \\
47 \text { \% } \\
58 \sigma^{7}\end{array}$ & $\begin{array}{l}7.50 \\
7.47 \\
7.52 \\
7.46\end{array}$ & $\begin{array}{l}7.45 \\
7.44 \\
7.50 \\
7.40\end{array}$ & $\begin{array}{l}35 \\
29 \\
30 \\
38\end{array}$ & $\begin{array}{l}41 \\
32 \\
33 \\
45\end{array}$ & $\begin{array}{l}5.49 \\
4.83 \\
6.85 \\
6.31\end{array}$ & $\begin{array}{l}4.91 \\
3.40 \\
5.78 \\
4.00\end{array}$ & $\begin{array}{l}51 \\
70 \\
39 \\
72\end{array}$ & $\begin{array}{r}55 \\
124 \\
48 \\
110\end{array}$ & $\begin{array}{l}2.8 \\
3.4 \\
2.7 \\
4.5\end{array}$ & $\begin{array}{l}2.7 \\
4.0 \\
2.8 \\
4.4\end{array}$ & & & & \\
\hline Mean & & 7.46 & 7.44 & 34 & 38 & 6.08 & 4.76 & 53 & 74 & $\begin{array}{l}3.1 \\
\mathrm{p}=\end{array}$ & $\begin{array}{r}3.2 \\
>0.6\end{array}$ & & & & \\
\hline
\end{tabular}

tween the controls and cirrhotics without encephalopathy listed together in Table II, and the subjects with hepatic encephalopathy listed in Table III.

Carbon dioxide inhalation failed to affect the cerebral oxygen uptake significantly either in controls or in those cirrhotics who lacked encephalopathy. The mean resting $\mathrm{CMR}_{\mathrm{O}_{2}}$ of controls and subjects without encephalopathy was $3.1 \mathrm{cc}$ per 100 $\mathrm{g}$ per minute, and during $\mathrm{CO}_{2}$ breathing this mean value rose insignificantly to $3.2 \mathrm{cc}$ per $100 \mathrm{~g}$ per minute. Only one subject decreased his $\mathrm{CMR}_{\text {O.2 }}$ more than $0.1 \mathrm{cc}$ per $100 \mathrm{~g}$ per minute. The cerebral metabolic response to inhaled $\mathrm{CO}_{2}$ was quite different in patients with hepatic encephalopathy: six of the eight tested patients showed significant $\mathrm{CMR}_{\mathrm{O}_{2}}$ reductions during $\mathrm{CO}_{2}$ breathing. Thus, the mean resting $\mathrm{CMR}_{\mathrm{O}_{2}}$ of patients having hepatic encephalopathy was 2.3 cc per $100 \mathrm{~g}$ per minute, and this mean value fell

TABLE III

Cerebral metabolic changes following $\mathrm{CO}_{2}$ inhalation in patients with hepatic encephalopathy

\begin{tabular}{|c|c|c|c|c|c|c|c|c|c|c|c|c|c|c|}
\hline & \multicolumn{2}{|c|}{ Art. pH } & \multicolumn{2}{|c|}{$\mathrm{PaCO}_{2}$} & \multicolumn{2}{|c|}{$\begin{array}{c}\text { Cerebral } \\
\mathrm{A}-\mathrm{VO}_{2}\end{array}$} & \multicolumn{2}{|c|}{$\mathrm{CBF}$} & \multicolumn{2}{|c|}{$\mathrm{CMRO}_{2}$} & \multicolumn{2}{|c|}{$\mathrm{A}-\mathrm{VNH}_{3}$} & \multicolumn{2}{|c|}{$\mathrm{CMRNH}_{3}$} \\
\hline & Air & $\mathrm{CO}_{2}$ & Air & $\mathrm{CO}_{2}$ & Air & $\mathrm{CO}_{2}$ & Air & $\mathrm{CO}_{2}$ & Air & $\mathrm{CO}_{2}$ & Air & $\mathrm{CO}_{2}$ & Air & $\mathrm{CO}_{2}$ \\
\hline$C$ and $?$ & & & \multicolumn{2}{|c|}{$m m H g$} & \multicolumn{2}{|c|}{ vol \% } & \multicolumn{2}{|c|}{$\underset{\mathrm{gl} / \mathrm{min}}{100}$} & \multicolumn{2}{|c|}{$\begin{array}{l}c c / 100 \\
\mathrm{~g} / \mathrm{min}\end{array}$} & \multicolumn{2}{|c|}{$\mu g / m l$} & \multicolumn{2}{|c|}{$\begin{array}{c}\mu g / 100 \\
g / \min \end{array}$} \\
\hline $\begin{array}{l}\text { G.L. } \\
\text { L.J.* } \\
\text { C.K. }{ }^{*}\end{array}$ & $\begin{array}{l}7.45 \\
7.47 \\
7.53\end{array}$ & $\begin{array}{l}7.43 \\
7.42 \\
7.51\end{array}$ & $\begin{array}{l}33 \\
27 \\
34\end{array}$ & $\begin{array}{l}35 \\
31 \\
36\end{array}$ & $\begin{array}{l}6.76 \\
7.54 \\
5.85\end{array}$ & $\begin{array}{l}5.26 \\
3.88 \\
3.14\end{array}$ & $\begin{array}{l}43 \\
43 \\
36\end{array}$ & $\begin{array}{l}46 \\
82 \\
36\end{array}$ & $\begin{array}{l}2.9 \\
3.2 \\
2.0\end{array}$ & $\begin{array}{l}2.3 \\
3.3 \\
1.0\end{array}$ & $2.61-2.29$ & $2.14-1.88$ & 11.52 & 9.36 \\
\hline \multicolumn{15}{|l|}{ Grade 3} \\
\hline $\begin{array}{l}\text { A.G. } \\
\text { F.H.* } \\
\text { E.L.* } \\
\text { A.G.* }\end{array}$ & $\begin{array}{l}7.49 \\
7.55 \\
7.51 \\
7.61\end{array}$ & $\begin{array}{l}7.49 \\
7.46 \\
7.34 \\
7.55\end{array}$ & $\begin{array}{l}35 \\
35 \\
24 \\
28\end{array}$ & $\begin{array}{l}36 \\
42 \\
38 \\
34\end{array}$ & $\begin{array}{l}5.47 \\
6.32 \\
5.42 \\
6.43\end{array}$ & $\begin{array}{l}4.49 \\
5.35 \\
1.80 \\
3.51\end{array}$ & $\begin{array}{l}51 \\
34 \\
32 \\
33\end{array}$ & $\begin{array}{l}53 \\
36 \\
70 \\
43\end{array}$ & $\begin{array}{l}2.8 \\
2.2 \\
1.8 \\
2.1\end{array}$ & $\begin{array}{l}2.4 \\
1.9 \\
1.3 \\
1.5\end{array}$ & $3.54-3.40$ & $3.38-3.32$ & 5.78 & 2.16 \\
\hline \multicolumn{15}{|l|}{ Grade 4} \\
\hline $\begin{array}{l}\text { B.F. } \\
\text { G.R. }\end{array}$ & $\begin{array}{l}7.57 \\
7.63\end{array}$ & $\begin{array}{l}7.42 \\
7.38\end{array}$ & $\begin{array}{l}27 \\
22\end{array}$ & $\begin{array}{l}40 \\
42\end{array}$ & $\begin{array}{l}8.05 \\
6.15\end{array}$ & $\begin{array}{l}3.39 \\
1.70\end{array}$ & $\begin{array}{l}20 \\
28\end{array}$ & $\begin{array}{l}45 \\
60\end{array}$ & $\begin{array}{l}1.6 \\
1.8\end{array}$ & $\begin{array}{l}1.5 \\
1.0\end{array}$ & $2.40-1.63$ & $1.93-1.78$ & 15.40 & 6.75 \\
\hline Mean & 7.53 & 7.44 & 29 & 37 & 6.44 & 3.61 & 36 & 52 & $\stackrel{2.3}{p=}$ & $\begin{array}{l}1.8 \\
0.01\end{array}$ & & & & \\
\hline
\end{tabular}

* Clinically deteriorated with $\mathrm{CO}_{2}$. 
TABLE IV

Change in cerebral metabolism after acetazolamide in control patients

\begin{tabular}{|c|c|c|c|c|c|c|c|c|c|c|c|c|c|}
\hline \multirow{2}{*}{$\begin{array}{c}\text { Name, } \\
\text { Age, Sex }\end{array}$} & \multirow{2}{*}{$\begin{array}{l}\text { Acetazolamide } \\
\text { dose }\end{array}$} & \multicolumn{2}{|c|}{ Art. $\mathrm{pH}$} & \multicolumn{2}{|c|}{$\begin{array}{c}\text { Cerebral } \\
\text { A-Vo2 }\end{array}$} & \multicolumn{2}{|c|}{$\mathrm{CBF}$} & \multicolumn{2}{|c|}{$\mathrm{CMRO}_{2}$} & \multicolumn{2}{|c|}{ A-VNH3 } & \multicolumn{2}{|c|}{$\mathrm{CMRNH}_{3}$} \\
\hline & & Rest & Acet. & Rest & Acet. & Rest & Acet. & Rest & Acet. & Rest & Acet. & Rest & Acet. \\
\hline & $g$ & & & \multicolumn{2}{|c|}{ vol $\%$} & \multicolumn{2}{|c|}{$\underset{\mathrm{gl} / \mathrm{min}}{\mathrm{m} / 100}$} & \multicolumn{2}{|c|}{$\begin{array}{l}c c / 100 \\
\mathrm{~g} / \mathrm{min}\end{array}$} & \multicolumn{2}{|c|}{$\mu g / m l$} & \multicolumn{2}{|c|}{$\mu \mathrm{g} / 100 \mathrm{ml} / \mathrm{min}$} \\
\hline $\begin{array}{l}\text { O.M. } 57 \sigma^{7} \\
\text { A.Q. } 68 \sigma^{7} \\
\text { E.B. } 71 \sigma^{7} \\
\text { H.D. } 53 \sigma^{7} \\
\text { O.W. } 59 \sigma^{7}\end{array}$ & $\begin{array}{l}1 \\
2 \\
2 \\
2 \\
2\end{array}$ & $\begin{array}{l}7.52 \\
7.40 \\
7.50 \\
7.48 \\
7.45\end{array}$ & $\begin{array}{l}7.52 \\
7.37 \\
7.46 \\
7.44 \\
7.42\end{array}$ & $\begin{array}{l}5.49 \\
6.74 \\
6.08 \\
8.15 \\
5.93\end{array}$ & $\begin{array}{l}3.00 \\
3.01 \\
3.46 \\
3.91 \\
3.13\end{array}$ & $\begin{array}{l}46 \\
43 \\
38 \\
34 \\
50\end{array}$ & $\begin{array}{r}80 \\
101 \\
74 \\
78 \\
77\end{array}$ & $\begin{array}{l}2.5 \\
2.9 \\
2.3 \\
2.8 \\
3.0\end{array}$ & $\begin{array}{l}2.4 \\
3.0 \\
2.5 \\
3.0 \\
2.3\end{array}$ & $\begin{array}{l}2.29-2.05 \\
2.29-1.98 \\
1.71-1.88 \\
2.11-1.80\end{array}$ & $\begin{array}{l}2.02-2.01 \\
2.49-1.93 \\
1.75-1.86 \\
1.77-1.65\end{array}$ & $\begin{array}{c}10.3 \\
11.8 \\
-5.78 \\
15.50\end{array}$ & $\begin{array}{r}1.0 \\
41.5 \\
-8.58 \\
9.24\end{array}$ \\
\hline Mean & & & & & & & & $\begin{array}{l}2.8 \\
*=\end{array}$ & $\begin{aligned} & 2.7 \\
> & 0.8\end{aligned}$ & & & & \\
\hline
\end{tabular}

* Values calculated for patients receiving $2 \mathrm{~g}$ acetazolamide.

significantly $(\mathrm{p}=<0.01)$ to $1.8 \mathrm{cc}$ per $100 \mathrm{~g}$ per minute during $\mathrm{CO}_{2}$ breathing; only two of these eight patients with encephalopathy decreased their $\mathrm{CMR}_{\mathrm{O}_{2}}$ less than $0.3 \mathrm{cc}$ per $100 \mathrm{~g}$ per minute.

Cerebral ammonia uptake. Four patients had arterial and venous ammonia levels measured while $\mathrm{CO}_{2}$ responses were being determined (Tables II and III). All showed decreased arterial ammonia levels and decreased cerebral ammonia uptakes $\left(\mathrm{CMR}_{\mathrm{NH}_{3}}\right)$ during the carbon dioxide inhalation. Two of the four patients had a decreased $\mathrm{CMR}_{\mathrm{O}_{2}}$, concomitant with the decreased ammonia uptake.

\section{Effect of acetazolamide infusions}

Clinical response. No clinical change was observed during the metabolic testing period in any of the noncirrhotic controls receiving acetazolamide. Later, starting 2 hours after the procedure and persisting for approximately 12 hours, one control patient (H.D.) developed drowsiness, nausea and facial paresthesias. Two cirrhotic patients receiving acetazolamide, 0.5 to $1 \mathrm{~g}$ showed no clinical change during or after the procedure.

Five patients ${ }^{1}$ with hepatic encephalopathy deteriorated neurologically when given $2 \mathrm{~g}$ acetazolamide. Starting 20 to 30 minutes after the injection their lethargy, confusion and disorientation worsened, their dysarthria progressed and their metabolic-type tremor increased in frequency and amplitude. The changes, whose degree was alarming in one subject (T.H.), were temporary and

1 One patient (M.S., with hepatitis) was examined clinically only and is not included in the metabolic data. lasted from 6 to 24 hours. No permanent sequelae were obsierved.

Cerebral oxygen uptake. Table IV presents the metabolic changes which followed acetazolamide injection in controls, and Table $\mathrm{V}$ presents these changes in subjects with hepatic encephalopathy. Figure 3 compares the $\mathrm{CMR}_{\mathrm{O}_{2}}$ responses between the two groups. Every subject, both control and cirrhotic, exhibited an arterial $\mathrm{pH}$ fall after acetazolamide. Five hundred $\mathrm{mg}$, or $1 \mathrm{~g}$ dosages evoked no blood pressure response, but when $2 \mathrm{~g}$ acetazolamide was administered, both control and cirrhotic subjects consistently developed a blood pressure rise (mean $20 \mathrm{~mm} \mathrm{Hg}$ ). Every patient, whether a control or cirrhotic, increased his cerebral blood flow considerably when

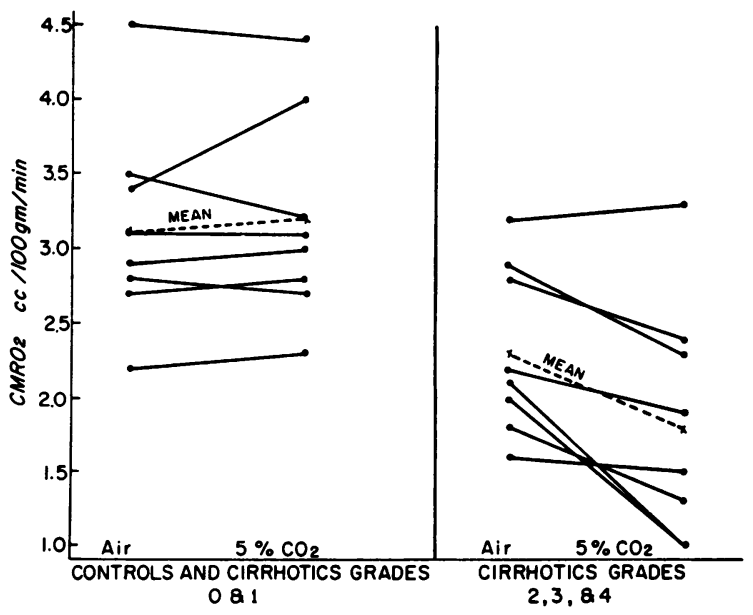

Fig. 2. Cerebral oXYgen UPtake in Liver Disease PATIENTS AT REST (BREATHING AIR) AND DURING 5 PER CENT CARBON DIOXIDE INHALATION. 


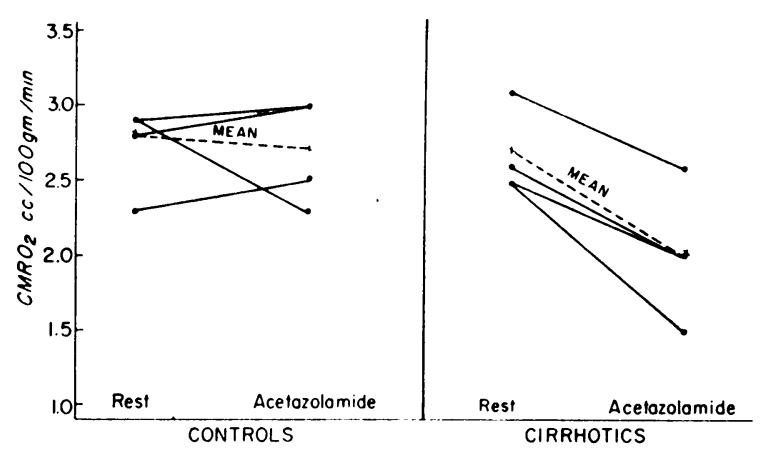

Fig. 3. Cerebral oxygen consumption at REST AND FOLLOWING 2 G ACETAZOLAMIDE, INTRAVENOUSLY, IN CONtrols and cirrhotics With Grade 2 encephalopathy.

given either 1 or $2 \mathrm{~g}$ acetazolamide. The cerebral oxygen uptake $\left(\mathrm{CMR}_{\mathrm{O}_{2}}\right)$ of control subjects showed no significant $(\mathrm{p}=>0.8)$ mean change following acetazolamide in either 1 or $2 \mathrm{~g}$ amounts. Similarly, the cerebral oxygen uptake of patients with hepatic encephalopathy was unaltered when only 0.5 or $1 \mathrm{~g}$ of acetazolamide was given. However, when the infused acetazolamide dosage was raised to $2 \mathrm{~g}$ (the dose required to raise blood pressure), every patient with hepatic encephalopathy showed a significant $(\mathrm{p}=<0.02>0.01)$ $\mathrm{CMR}_{\mathrm{O}_{2}}$ drop, the smallest decline being $0.5 \mathrm{cc}$ per $100 \mathrm{~g}$ per minute.

Cerebral ammonia uptake. Four controls and all of the subjects with hepatic encephalopathy had arterial and venous ammonia levels measured while acetazolamide effects (Tables IV and V) were being determined. Neither the arterial blood ammonia level nor the cerebral ammonia uptake showed any changes correlating with the clinical or metabolic response to acetazolamide. Thus, arterial ammonias either decreased or stayed the same while cerebral ammonia uptake $\left(\mathrm{CMR}_{\mathrm{NH}_{3}}\right)$ increased in some subjects and decreased in others.

\section{DISCUSSION}

Correlation of cerebral metabolism and encephalopathy. Our data are consistent with those of Kety (24) and Lassen (25), and show that, in metabolic encephalopathy, when psychological and somatic neurological abnormalities develop, they are accompanied by measurably impaired cerebral metabolism. Although there was some overlap between individual cases, the clinical estimate of the grade of encephalopathy and the mean $\mathrm{CMR}_{\mathrm{O}_{2}}$ reduction correlated directly and quantitatively. Thus, cirrhotic patients graded 0 or 1 (no clinical encephalopathy) had no cerebral oxygenation depression, Grades 2 and 3 had mean oxygen uptakes of $2.9 \mathrm{cc}$ and $2.0 \mathrm{cc}$ per $100 \mathrm{~g}$ brain per minute, respectively, and the two Grade 4 (comatose) patients had brain oxygen consumptions less than $2.0 \mathrm{cc}$ per $100 \mathrm{~g}$ per minute. The data differ from the observation of Fazekas and associates (8) that

TABLE V

Change in cerebral metabolism after acetazolamide in patients with encephalopathy

\begin{tabular}{|c|c|c|c|c|c|c|c|c|c|c|c|c|c|}
\hline \multirow[b]{2}{*}{ Name } & \multirow{2}{*}{$\begin{array}{l}\text { Acetazolamide } \\
\text { dose }\end{array}$} & \multicolumn{2}{|c|}{ Art. $\mathrm{pH}$} & \multicolumn{2}{|c|}{$\begin{array}{c}\text { Cerebral } \\
\text { A-Vo2 }\end{array}$} & \multicolumn{2}{|c|}{$\mathrm{CBF}$} & \multicolumn{2}{|c|}{$\mathrm{CMRO}_{2}$} & \multicolumn{2}{|c|}{$\mathrm{A}-\mathrm{VNH}_{3}$} & \multicolumn{2}{|c|}{$\mathrm{CMRNH}_{3}$} \\
\hline & & Rest & Acet. & Rest & Acet. & Rest & Acet. & Rest & Acet. & Rest & Acet. & Rest & Acet. \\
\hline & $g$ & & & \multicolumn{2}{|c|}{ vol \% } & \multicolumn{2}{|c|}{$\underset{\mathrm{gl} / \mathrm{min}}{\mathrm{moO}}$} & \multicolumn{2}{|c|}{$\begin{array}{l}c c / 100 \\
\mathrm{~g} / \mathrm{min}\end{array}$} & \multicolumn{2}{|c|}{$\mu g / m l$} & \multicolumn{2}{|c|}{$\begin{array}{l}\mu \mathrm{g} / 100 \\
\mathrm{ml} / \mathrm{mm}\end{array}$} \\
\hline Grade 4 & & & & & & & & & & & & & \\
\hline B.F. & 1 & 7.52 & 7.51 & 7.38 & 3.68 & 18 & 33 & 1.3 & 1.2 & $2.40-1.64$ & $1.80-1.76$ & 13.7 & 1.3 \\
\hline \multicolumn{14}{|l|}{ Grade 2} \\
\hline $\begin{array}{l}\text { C. } K . \\
\text { C. K. }\end{array}$ & $\begin{array}{l}0.5 \\
1.0\end{array}$ & $\begin{array}{l}7.52 \\
7.49\end{array}$ & $\begin{array}{l}7.51 \\
7.44\end{array}$ & $\begin{array}{l}6.63 \\
5.05\end{array}$ & $\begin{array}{l}4.86 \\
3.11\end{array}$ & $\begin{array}{l}45 \\
59\end{array}$ & $\begin{array}{r}57 \\
102\end{array}$ & $\begin{array}{l}2.9 \\
3.0\end{array}$ & $\begin{array}{l}2.8 \\
3.2\end{array}$ & $\begin{array}{l}2.87-2.56 \\
3.57-3.40\end{array}$ & $\begin{array}{l}2.94-2.74 \\
3.38-3.32\end{array}$ & $\begin{array}{l}13.9 \\
10.0\end{array}$ & $\begin{array}{r}11.4 \\
6.1\end{array}$ \\
\hline \multicolumn{14}{|c|}{ Grades 2-3 } \\
\hline $\begin{array}{l}\text { F.H. } \\
\text { T.L. } \\
\text { H.D. } \\
\text { M.P. }\end{array}$ & $\begin{array}{l}2 \\
2 \\
2 \\
2\end{array}$ & $\begin{array}{l}7.62 \\
7.51 \\
7.47\end{array}$ & $\begin{array}{l}7.59 \\
7.47 \\
7.46\end{array}$ & $\begin{array}{l}6.00 \\
5.20 \\
6.97 \\
6.19\end{array}$ & $\begin{array}{l}3.30 \\
2.07 \\
2.75 \\
2.54\end{array}$ & $\begin{array}{l}44 \\
48 \\
36 \\
50\end{array}$ & $\begin{array}{r}62 \\
73 \\
72 \\
103\end{array}$ & $\begin{array}{l}2.6 \\
2.5 \\
2.5 \\
3.1\end{array}$ & $\begin{array}{l}2.0 \\
1.5 \\
2.0 \\
2.6\end{array}$ & $\begin{array}{l}2.84-2.44 \\
4.12-4.12 \\
2.48-2.15 \\
2.86-2.69\end{array}$ & $\begin{array}{l}2.56-2.41 \\
4.05-3.90 \\
2.38-2.34 \\
2.91-2.68\end{array}$ & $\begin{array}{c}17.2 \\
0 \\
11.9 \\
8.5\end{array}$ & $\begin{array}{r}9.3 \\
10.9 \\
2.9 \\
23.4\end{array}$ \\
\hline Mean & & & & & & & & 2.7 & 2. & & & & \\
\hline
\end{tabular}

* Values calculated for patients receiving $2 \mathrm{~g}$ acetazolamide. 
mentally alert cirrhotic patients show depressed oxygen consumptions with a mean of $2.3 \mathrm{cc}$ per $100 \mathrm{~g}$ per minute. Unless they included Group 2 patients among those classified as "alert" (26), no explanation for Fazekas' unique experience is forthcoming. Although our Group 4 sample is small, our data also fail to confirm Fazekas' finding that comatose patients showed a $\mathrm{CMR}_{\mathrm{O}_{2}}$ no lower than still-conscious subjects.

Relationship of encephalopathy, arterial blood $p H$ and respiratory gases. Respiratory alkalosis is one of the most consistent biochemical accompaniments of severe liver disease and few of the present subjects lacked this change, whether or not they showed neurological impairment. Vanamee and associates (1) reported that 25 out of 29 patients with hepatic encephalopathy were alkalotic, and others $(4,27)$ have observed similar findings. If frankly acidotic patients (those with renal failure) are omitted from the data of the Vanamee group, the mean blood $\mathrm{pH}$ rose progressively as encephalopathy increased. Tyor and Sieker (4), although confirming the nearubiquity of arterial blood alkalosis, noted less correlation between the absolute $\mathrm{pH}$ level and the degree of encephalopathy. However, Tyor and Sieker did find in individual cases that the arterial $\mathrm{pH}$ rose as encephalopathy progressed. Robin, Whaley, Crump and Travis (27) noted no correlation between arterial hypocapnia and state of consciousness. Our own data correspond more with Vanamee's, since the mean arterial blood $\mathrm{pH}$ rose as encephalopathy progressed from Grade 0 to Grade 4. Despite the $\mathrm{pH}$ rise, hyperventilation was evident clinically only when neurological changes were pronounced (Grades 3, 4).

Arterial $\mathrm{Pa}_{\mathrm{CO}_{2}}$ levels were depressed commensurately with the degree of alkalosis, being lowest among comatose subjects. Alkalosis and hypocapnia reduce cerebral blood flow (10) and impair alertness and equilibrium in the hyperventilation syndrome (28). Reduction of $\mathrm{Pa}_{\mathrm{CO}_{2}}$ comparable with that seen in hepatic encephalopathy produces electroencephalographic (EEG) abnormalities in animals (29), indicating cerebral dysfunction. Despite the evidence that hypocapnia sometimes is deleterious, it seems doubtful that low blood carbon dioxide levels contribute importantly to hepatic encephalopathy. Hyperventilation dur- ing routine adult human EEG recordings seldom produces marked slowing unless epilepsy or hypoglycemia (30) is present. Some cirrhotic patients with intact mentation and cerebral metabolism show just as much hypocapnia as do others in coma (Table I) $(1,4)$. Hyperventilation alkalosis comparable with that of liver disease failed to depress cerebral metabolism in Kety and Schmidt's normal subjects (10). Finally, reversing hypocapnia with $\mathrm{CO}_{2}$ therapy in the present study failed to ameliorate either the clinical or the metabolic manifestations of encephalopathy.

The arterial oxygen desaturation which accompanies all grades of hepatic encephalopathy (Table I) is usually modest. However, because of the respiratory alkalosis of advanced cirrhosis, the resultant $\mathrm{Pa}_{\mathrm{O}_{2}}$ is considerably lower at any given oxygen saturation than would be the case if $\mathrm{pH}$ were normal (9). As a result, several cirrhotics in the present study showed alarmingly low $\mathrm{Pa}_{\mathrm{O}_{2}}$ values. Although this depression of available oxygen may be an unfavorable influence in hepatic encephalopathy, it is an unlikely cause for the condition, since no correlation was observed by either ourselves or others (4) between mean $\mathrm{Pa}_{\mathrm{O}_{2}}$ and depth of coma. The low values do suggest that oxygen therapy might be a useful adjunct to treating seriously ill patients with liver disease.

The mechanism of alkalosis in liver disease. The alkalosis of severe liver disease is clearly due to relative overbreathing, although the hyperventilation usually remains moderate and clinically unapparent until severe encephalopathy develops. The moderate anoxemia which often accompanies cirrhosis $(4,31,32)$ is insufficient to account for the hyperpnea (33). Peripheral reflexes from the lungs stimulating the respiration (34) have not been examined. Lacking evidence for other mechanisms, most workers who have studied the problem $(11,32,35)$ speculate that the hyperventilation of cirrhosis arises centrally, presumably from biochemical stimulation of respiratory center neurons.

Examples of central hyperventilation in other diseases exist, although the respiratory changes are rare in the absence of other manifestations of neurological impairment. Thus, when hyperpnea develops in metabolic acidosis, consciousness is usu- 
ally impaired. Similarly, the hyperventilation which is seen with medial pontine tegmental lesions in man is accompanied by profound neurological dysfunction in nonrespiratory spheres (36). The clinical picture of severe metabolic encephalopathy with coma, muscular rigidity, fixed extraocular movements and sustained evident hyperpnea closely resembles the signs and symptoms which follow medial pontine infarction. However, hyperpnea is seen in patients with liver cirrhosis long before any other sign of presumed neurological dysfunction. This suggests that either brain stem respiratory-controlling neurons have an extraordinary susceptibility to the metabolic dysfunction of liver disease or that peripheral stimulating mechanisms need closer study than they have heretofore received.

If hyperventilation in liver disease does have a central origin, the biochemical process that either stimulates facilitatory neurons or blocks normally inhibitory respiratory nerve cells is presently unknown. Roberts, Thompson, Poppell and Vanamee (11), Sherlock (35) and others have considered raised blood ammonia to cause hyperventilation, pre umably by directly stimulating the respiratory centers. Evidence to support this supposition is conflicting. There are reports that hyperventilation follows ammonia infusions in dogs (11), mice (14) and men (37). However, another carefuly controlled and detailed human experiment (38) showed no significant arterial blood $\mathrm{pH}$ change during ammonia infusions that produced arterial blood ammonia levels exceeding $500 \mu \mathrm{g}$ per $100 \mathrm{ml}$. Ammonium salts infused directly into dogs' carotid arteries produced only slight and transient arterial blood $\mathrm{pH}$ elevations (39). These observations plus the lack of correlation between arterial blood ammonia, and either $\mathrm{pH}$ (4) or minute ventilation (32) reduce the likelihood that ammonia, per se, contributes significantly to hyperventilation in severe liver disease.

Another mechanism to produce central hyperventilation would be through presently unknown acid metabolites accumulating intracellularly in the brain stem respiratory centers. Advanced liver disease probably disrupts the Krebs cycle, since increased levels of pyruvate and glutamate have been found in the cerebrospinal fluid ( 40 ,
41). Hyperventilation and extracellular alkalosis would be compensatory and protective if caused by intracellular acidity of central respiratory neurons. Unfortunately, no present methods exist to explore this speculation in man.

The toxicity of carbon dioxide. Carbon dioxide inhalation clearly harmed cirrhotic patients with encephalopathy, producing both clinical deterioration and a decreased $\mathrm{CMR}_{\mathrm{O}_{2}}$. The deterioration could not be attributed to rising ammonia levels since both arterial ammonia levels and cerebral ammonia uptakes fell during $\mathrm{CO}_{2}$, breathing in all instances presented here. (More extensive data are presented elsewhere indicating that in normal subjects as well as in cirrhotics, respiratory alkalosis raises blood ammonia while $\mathrm{CO}_{2}$ breathing lowers it (42). Moreover, reducing the blood $\mathrm{pH}$ decreases the partial pressure of gaseous, diffusible ammonia $(14,43)$, and this alone should lessen the brain uptake.) Also, the deterioration could not be attributed to deleterious effects resulting from the muscular efforts of $\mathrm{CO}_{2}$-induced hyperpnea, since similar deterioration without hyperpnea followed increasing tissue $\mathrm{CO}_{2}$ tensions with acetazolamicle.

Carbon dioxide is a toxic gas, although concentrations higher than those employed here usually are required for toxic effect. Inhaling 10 per cent $\mathrm{CO}_{2}$ can make normal persons comatose (44). Since the subjects with hepatic encephalopathy had a low resting $\mathrm{Pa}_{{ }^{\prime} \mathrm{O}_{2}}$, breathing 5 per cent carbon dioxide produced a proportionately greater increase in blood and tissue $\mathrm{CO}_{2}$ tensions than would have been produced in normals. However, several Grade 0 and Grade 1 subjects also had low resting $\mathrm{Pa}_{\mathrm{Co}_{2}}:$, yet suffered no ill effects during $\mathrm{CO}_{2}$ inhalation. Thus, the toxic responses to 5 per cent carbon dioxide could not be explained merely by different proportionate increases resulting from chronic hypocapnia.

Pre-existing cerebral metabolic derangements enhance the brain's susceptibility to many pharmacological depressants given in ordinarily innocuous dosages. Patients with structural brain disease frequently react unfavorably to modest doses of barbiturates, alcohol or anticonvulsants. This phenomenon may partially explain $\mathrm{CO}_{2}$ toxicity in hepatic encephalopathy and also could explain why ammonia is sometimes toxic for patients with 
liver disease although equivalent levels are harmless for normal subjects (38).

How carbon dioxide specificially affects nerve cell metabolism is unknown, although the gas alters the function of central neurons extending far beyond the respiratory centers (29). If the speculation that accumulating intracellular acid metabolites cause hepatic encephalopathy proved to be true, this would readily explain why carbon dioxide is toxic. The diffusibility of $\mathrm{CO}_{2}$ across membranes rapidly makes the cerebral spinal fluid (45) and, presumably, brain cells more acidic. Other acid radicals have no such prompt effect (46). Thus, carbon dioxide would particularly intensify the already existing biochemical disturbance. In any case, there is little present evidence that respiratory alkalosis harms cirrhotics, and it is apparent that using carbon dioxide to reverse the alkalosis increases the encephalopathy.

The mechanism of acetazolamide toxicity. Clinical and cerebral metabolic deterioration was prompt and striking in the patients with hepatic encephalopathy who received $2 \mathrm{~g}$ of intravenous acetazolamide. Indeed, the response was such that we felt unjustified in extending the study to a larger group of cirrhotics.

Acetazolamide is not an inherently toxic drug. Normal subjects sometimes develop drowsiness and paresthesias after receiving doses of the drug exceeding $1 \mathrm{~g}$ (47-49), and such a response was observed to begin about 2 hours after infusion in one of our controls. This response, whose mechanism is unknown, was qualitatively entirely different from the increased confusion and mental obtundity found in the cirrhotics, and the time delay was also dissimilar to the cirrhotics' immediate worsening.

The toxic effects of acetazolamide in hepatic encephalopathy described here appear to be best explained as resulting directly from increased cerebral $\mathrm{CO}_{2}$ tensions. Several things suggest this conclusion.

1. Acetazolamide's only known direct metabolic effect is carbonic anhydrase inhibition (50), which increases venous and tissue $\mathrm{P}_{\mathrm{CO}_{2}}$ (51).

2. Significant $\mathrm{CMR}_{\mathrm{O}_{2}}$ reduction in hepatic encephalopathy followed $2 \mathrm{~g}$ doses of acetazolamide but not lesser doses. The Henderson-Hasselbalch equation is not applicable to calculate blood gas tensions when carbonic anhydrase is inhibited (52), but two observations in this study suggested that $2 \mathrm{~g}$ of infused acetazolamide produced more $\mathrm{CO}_{2}$ retention than did $1 \mathrm{~g}$ of the drug. Thus, the mean blood pressure rose only in subjects receiving the $2 \mathrm{~g}$ dose (53), and the subjects receiving $2 \mathrm{~g}$ showed a mean $\mathrm{CBF}$ rise of 87 per cent while subjects receiving $1 \mathrm{~g}$ or less of acetazolamide showed a mean $\mathrm{CBF}$ rise of but 62 per cent.

3. No consistent arterial ammonia rise accompanied the immediate clinical and cerebral metabolic deterioration which followed acetazolamide. As a secondary result of acetazolamide's inhibiting renal tubular carbonic anhydrase, urine ammonia falls and renal vein ammonia rises $(54,55)$. Consequently, after a period of time, the arterial ammonia rises in those cirhotics who have a decreased hepatic ammonia uptake. Owen, Flanagan, Berry and Tyor (56) found this rise 45 minutes after acetazolamide injection, and Webster and Kleinerman (57) noted a 24 per cent arterial ammonia increase 1 hour after injecting acetazolamide. Our data, which show no blood ammonia rise 30 minutes after acetazolamide, indicate that more than 30 minutes is required for impaired renal output to increase arterial ammonia.

Previously, the secondary ammonia rise described above has been regarded as the likely mechanism for acetazolamide's toxicity in patients with hepatic cirrhosis (58). The observations presented here suggest that acetazolamide's major toxic effect may be more direct and due to the increased cerebral $\mathrm{CO}_{2}$ tensions resulting from carbonic anhydrase inhibition.

\section{SUMMARY}

1. Arterial blood gases, cerebral blood flows and cerebral oxygen uptakes were determined in control subjects, alert cirrhotic patients and patients with varying degrees of hepatic encephalopathy. The clinical and cerebral metabolic responses to inhaled 5 per cent carbon dioxide and to infused acetazolamide were tested in both cirrhotics and controls.

2. Alert cirrhotic patients had respiratory alkalosis and the degree of alkalosis increased progressively as encephalopathy appeared and worsened.

3. The cerebral oxygen uptake was normal in alert cirrhotics, but the uptake progressively de- 
creased as hepatic encephalopathy developed and worsened.

4. Five per cent carbon dioxide produced no adverse effects on alert cirrhotics or patients with static brain disease. However, inhaling 5 per cent $\mathrm{CO}_{2}$ caused both clinical deterioration and significantly decreased cerebral oxygen uptake in patients having hepatic encephalopathy. The arterial blood ammonia decreased and the cerebral ammonia uptake declined during $\mathrm{CO}_{2}$ inhalation.

5. Acetazolamide infusions produced no significant clinical or cerebral metabolic rate (CMR) changes in control subjects. Patients with hepatic encephalopathy showed no $\mathrm{CMR}_{\mathrm{O}_{2}}$ change when given 0.5 or $1 \mathrm{~g}$ of the drug. However, when patients with hepatic encephalopathy received $2 \mathrm{~g}$ of acetazolamide, they promptly deteriorated clinically and significantly decreased their cerebral oxygen consumption. The arterial ammonia level did not increase in any instance.

6. This study suggests that the toxicity of acetazolamide in hepatic encephalopathy directly results from increased cerebral tissue carbon dioxide tensions. It is postulated that respiratory alkalosis in advanced liver disease is compensatory, acting to protect rather than to impair brain function.

\section{ACKNOWLEDGMENT}

The valuable technical assistance of Mrs. Else S. Vreede is gratefully acknowledged.

\section{REFERENCES}

1. Vanamee, P., Poppell, J. W., Glicksman, A. S., Randall, H. T., and Roberts, K. E. Respiratory alkalosis in hepatic coma. A. M. A. Arch. intern. Med. 1956, 97, 762.

2. Phear, E. A., Sherlock, S., and Summerskill, W. H. $\mathrm{J}$. Blood-ammonium levels in liver disease and "hepatic coma." Lancet 1955, 1, 836.

3. Schwartz, R., Phillips, G. B., Gabuzda, G. J., Jr., and Davidson, C. S. Blood ammonia and electrolytes in hepatic coma. J. Lab. clin. Med. 1953, 42, 499.

4. Tyor, M. P., and Sieker, H. O. Biochemical, blood gas and peripheral circulatory alterations in hepatic coma. Amer. J. Med. 1959, 27, 50.

5. Bessman, S. P., and Bessman, A. N. The cerebral and peripheral uptake of ammonia in liver disease with an hypothesis for the mechanism of hepatic coma. J. clin. Invest. 1955, 34, 622.
6. Webster, L. T., Jr., and Gabuzda, G. J. Ammonium uptake by the extremities and brain in hepatic coma. J. clin. Invest. 1958, 37, 414.

7. Wechsler, R. L., Crum, W., and Roth, J. L. A. The blood flow and oxygen consumption of the human brain in hepatic coma. Clin. Res. Proc. 1954, 2,74 .

8. Fazekas, J. F., Ticktin, H. E., Ehrmantraut, W. R., and Alman, R. W. Cerebral metabolism in hepatic insufficiency. Amer. J. Med. 1956, 21, 843.

9. Carryer, H. M. Tissue anoxia resulting from rerespiratory alkalosis. Proc. Mayo Clin. 1947, 22, 456.

10. Kety, S. S., and Schmidt, C. F. The effects of active and passive hyperventilation on cerebral blood flow, cerebral oxygen consumption, cardiac output, and blood pressure of normal young men. J. clin. Invest. 1946, 25, 107.

11. Roberts, K. E., Thompson, F. G., III, Poppell, J. W., and Vanamee, P. Respiratory alkalosis accompanying ammonium toxicity. J. appl. Physiol. 1956, 9, 367.

12. Warren, K. S, and Nathan, D. G. The passage of ammonia across the blood-brain-barrier and its relation to blood $\mathrm{pH}$. J. clin. Invest. 1958, 37, 1724.

13. Warren, K. S. The differential toxicity of ammonium salts. J. clin. Invest. 1958, 37, 497.

14. Roberts, K. E., Vanamee, P., Poppell, J. W., Rubin, A., Braveman, W., and Randall, H. T. Electrolyte alterations in liver disease and hepatic coma. Med. clin. N. Amer. 1956, 40, 901.

15. Adams, R. D., and Foley, J. M. The neurological disorder associated with liver disease. Ass. Res. nerv. Dis. Proc. 1953, 32, 198.

16. Myerson, A., Halloran, R. D., and Hirsch, H. L. Technic for obtaining blood from internal jugular vein and internal carotid artery. Arch. Neurol. Psychiat. (Chicago) 1927, 17, 807.

17. Scheinberg, P., and Stead, E. A., Jr. The cerebral blood flow in male subjects as measured by the nitrous oxide technique. Normal values for blood flow, oxygen utilization, glucose utilization, and peripheral resistance with observations on the effect of tilting and anxiety. J. clin. Invest. 1949, 28, 1163.

18. Kety, S. S., and Schmidt, C. F. The nitrous oxide method for the quantitative determination of cerebral blood flow in man: Theory, procedure and normal values. J. clin. Invest. 1948, 27, 476.

19. Strowd, M. W., Lambertsen, C. J., Wendel, H., and Daly, M. DeB. Comparison of continuous and intermittent sampling in nitrous oxide method for determining cerebral blood flow. Fed. Proc. 1954, $13,147$.

20. Peters, J. P., and Van Slyke, D. D. Quantitative Clinical Chemistry. Interpretations. Baltimore, Williams \& Wilkins, 1932, vol. 1, p. 939. 
21. Singer, R. B., and Hastings, B. An improved clinical method for the estimation of disturbances of the acid-base balance of human blood. Medicine (Baltimore) 1948, 27, 223.

22. Dittmer, D. S., and Grebe, R. M., Eds. Handbook of Respiration. Philadelphia, W. B. Saunders, 1958, pp. 46-98.

23. Seligson, D., and Hirahara, K. The measurement of ammonia in whole blood, erythrocytes, and plasma. J. Lab. clin. Med. 1957, 49, 962.

24. Kety, S. S. The physiology of the human cerebral circulation. Anesthesiology 1949, 10, 610.

25. Lassen, N. A. Cerebral blood flow and oxygen consumption in man. Physiol. Rev. 1959, 39, 183.

26. Engel, G. L., and Romano, J. Delirium, a syndrome of cerebral insufficiency. J. chron. Dis. 1959, 9, 260.

27. Robin, E. D., Whaley, R. D., Crump, C. H., and Travis, D. M. The nature of the respiratory acidosis of sleep and of the respiratory alkalosis of hepatic coma (abstract). J. clin. Invest. 1957, 36, 924.

28. Engel, G. L., Farris, E. B., and Logan, M. Hyperventilation: Analysis of clinical symptomatology. Ann. intern. Med. 1947, 27, 683.

29. Swanson, A. G., Stavney, L. S., and Plum, F. Effects of blood $\mathrm{pH}$ and carbon dioxide on cerebral electrical activity. Neurology 1958, 8, 787.

30. Heppenstall, M. E., and Greville, G. D. in Hill and Parr, Electroencephalography, A Symposium on its Various Aspects. New York, Macmillan, 1950, p. 127.

31. Murray, J. F., Dawson, A. M., and Sherlock, S. Circulatory changes in chronic liver disease. Amer. J. Med. 1958, 24, 358.

32. Heinemann, H. O., Emirgil, C., and Mijnssen, J. P. Hyperventilation and arterial hypoxia in cirrhosis of the liver. Amer. J. Med. 1960, 28, 239.

33. Gessell, R., Lapides, J., and Levin, M. The interaction of central and peripheral chemical control of breathing. Amer. J. Physiol. 1940, 130, 155.

34. Harrison, T. R. Failure of the Circulation. Baltimore, Williams \& Wilkins, 1939.

35. Sherlock, S. Pathogenesis and management of hepatic coma. Amer. J. Med. 1958, 24, 805.

36. Plum, F., and Swanson, A. G. Central neurogenic hyperventilation in man. Arch. Neurol. Psychiat. (Chicago) 1959, 81, 535.

37. Marossero, F., Migliore, A., and Pagni, C. A. Studio sperimentale dell'azione del cloruro d'ammonio per iniezione endovenosa rapida sui potenziali corticali di tipo convulsivo. Bull. Soc. ital. Biol. sper. 1957, 33, 90.

38. Wilson, W. P., and Tyor, M. P. Electroencephalographic observations during experimental hyperammonemia. Neurology 1958, 8, 913.
39. Eiseman, B., and Clark, G. M. Studies in ammonia metabolism. III. The experimental production of coma by carotid arterial infusion of ammonium salts. Surgery $1958,43,476$.

40. Amatuzio, D. S., and Nesbitt, S. A study of pyruvic acid in the blood, spinal fluid and urine of patients with liver disease with and without hepatic coma (abstract). J. clin. Invest. 1950, 29, 796.

41. Eiseman, B., Fowler, W. G., White, P. J., and Clark, G. M. The role of ammonia in the production of hepatic coma. Surg. Forum 1955, 6, 369.

42. Posner, J. B., and Plum, F. Effect of acute respiratory alkalosis and acidosis on blood ammonia. Clin. Res. 1960, 8, 30.

43. Jaquez, J. A., Poppell, J. W., Lawrence, W., Jr., and Roberts, K. E. The clinical significance of the partial perssure of ammonia in patients with ammonia toxicity. Clin. Res. Proc. 1957, 5, 20.

44. Goodman, L. S., and Gilman, A. The Pharmacological Basis of Therapeutics, 2nd ed. New York, Macmillan, 1955, p. 905.

45. Robin, E. D., Whaley, R. D., Crump, C. H., Bickelmann, A. G., and Travis, D. M. Acid-base relations between spinal fluid and arterial blood with special reference to control of ventilation. J. appl. Physiol. 1958, 13, 385.

46. Winterstein, $H$. Chemical control of pulmonary ventilation. III. The "reaction theory" of respiratory control. New Engl. J. Med. 1956, 255, 331.

47. Nadell, J. The effects of the carbonic anhydrase inhibitor " 6063 " on electrolytes and acid-base balance in two normal subjects and two patients with respiratory acidosis. J. clin. Invest. 1953, 32, 622 .

48. Friedberg, C. K., Taymor, R., Minor, J. B., and Halpern, M. The use of Diamox, a carbonic anhydrase inhibitor, as an oral diuretic in patients with congestive heart failure. New Engl. J. Med. 1953, 248, 883.

49. Belsky, H. Use of a new oral diuretic, Diamox, in congestive heart failure. New Engl. J. Med. 1953, 249, 140.

50. Berliner, R. W., and Orloff, J. Carbonic anhydrase inhibitors. Pharmacol. Rev. 1956, 8, 137.

51. Mithoefer, J. C., and Davis, J. S. Inhibition of carbonic anhydrase: Effect on tissue gas tensions in the rat. Proc. Soc. exp. Biol. (N. Y.) 1958, 98, 797.

52. Mithoefer, J. C. Inhibition of carbonic anhydrase: Its effect on elimination of carbon dioxide by the lungs. J. appl. Physiol. 1959, 14, 109.

53. Goldstein, J. D., and DuBois, E. L. Effect on the circulation in man of rebreathing different concentrations of carbon dioxide. Amer. J. Physiol. 1927, 81, 650.

54. Poppell, W. J., Cuajunco, F., Jr., Horsley, J. S., III, Randall, H. T., and Roberts, K. E. Renal arteriovenous ammonium difference and total renal 
ammonium production in normal, acidotic and alkalotic dogs. Clin. Res. Proc. 1956, 4, 137.

55. Berry, J. N., Flanagan, J. F., Owen, E. E., and Tyor, M. P. The kidney as a source of blood ammonia in resting and hyperventilated cirrhotics. Clin. Res. 1959, 7, 154.

56. Owen, E. E., Flanagan, J. F., Berry, J. N., and Tyor, M. P. The kidney as a source of blood ammonia in patients with liver disease: The effect of Diamox. Clin. Res. 1959, 7, 292.
57. Webster, L. T., Jr., and Kleinerman, J. Effect of a carbonic anhydrase inhibitor, acetazoleamide (Dia$\operatorname{mox}{ }^{\circledR)}$ on cerebral "ammonium" metabolism of patients with and without hepatic cirrhosis (abstract). J. clin. Invest. 1957, 36, 934.

58. Webster, L. T., Jr., and Davidson, C. S. Production of impending hepatic coma by a carbonic anhydrase inhibitor, Diamox. Proc. Soc. exp. Biol. (N. Y.) 1956, 91, 27. 